ГАДЖИМУРАДОВА Гюльнара Ильясбековна - кандидат философских наук, доцент кафедры демографической и миграционной политики Московского государственного института международных отношений (университет) МИД РФ (119454, Россия, г. Москва, пр-кт Вернадского, 76; gadzhimuradova7@gmail.com); ведущий научный сотрудник Института социально-политических исследований РАН (119333, Россия, г. Москва, ул. Фотиевой, 6, стр. 1)

\title{
ОСНОВНЫЕ АСПЕКТЫ МИГРАЦИОННОЙ ПОЛИТИКИ ШВЕЦИИ И ФИНЛЯНДИИ
}

Аннотация. В статье дан сравнительный анализ некоторых аспектов миграционной политики Швеции и Финляндии. Автор приводит ретроспективу миграционной истории двух стран и современное положение дел в отношении пребывания лиц, ищущих убежища, и беженцев на территории Швеции и Финляндии.

Ключевые слова: миграция, иммигранты, миграционная политика, Северная Европа

$\Phi$ инляндия и Швеция имеют различный опыт в области приема иммигрантов. В то время как шведское общество было открыто для иммиграции и мультикультурализма на протяжении десятилетий вследствие политики «открытых дверей», Финляндия не была столь привлекательна для иммигрантов. Для сравнения, в 2016 г. в Финляндии проживали всего 243639 иностранных граждан, что составляет 4\% общей численности населения (около 5,5 млн чел.), в 2017 г. их число увеличилось до 249452 чел. ${ }^{1}$ Число иностранных граждан в Швеции в 2016 г. составляло 851949 чел., или 8,5\% общей численности населения (10 млн чел.), в 2017 г. - 897336 чел. $^{2}$ В целом за пределами страны родились до 1,8 млн жителей Швеции (17,8\% населения), а в Финляндии 296 тыс. чел. (5,3\% населения).

Стремительное старение населения, характерное для большинства стран Европы, повышение продолжительности жизни, увеличение возраста вступления в брак, распространение малодетной или бездетной моделей семьи и нетрадиционных сексуальных отношений является реальностью современной Европы. Эта ситуация спровоцировала проблему сокращения трудовых ресурсов. И если вплоть до конца 1920-х гг. Швеция в силу экономических проблем была государством, из которого эмигрировали в более благополучные страны, такие как Америка и Канада, то с середины XX в. она постепенно стала превращаться в страну-реципиента. В Швецию в поисках работы ехали жители соседних с ней стран: Дании, Финляндии, Норвегии. Культурный код приезжих не вступал в особые противоречия с местными традициями и обычаями, поэтому приток иммигрантов в страну имел в основном положительный эффект.

Со второй половины XX в. активизировался поток иммигрантов из Южной и Восточной Европы, стран Азии и Африки, а в период миграционного кризиса 2014-2016 гг. - и из государств Ближнего Востока, охваченных политическим и экономическим кризисом.

События Арабской весны, миграционный кризис и борьба с терроризмом сделали особо значимыми проблемы интеграции иммигрантов из стран Ближнего Востока, являющихся в основном мусульманами. Стремительный рост числен-

\footnotetext{
1 Immigrants in the population. - Statistics Finland. URL: http://www.stat.fi/tup/maahanmuutto/ maahanmuuttajat-vaestossa_en.html (accessed 22.10.2019).

2 Number of persons who have acquired Swedish citizenship by region, age and sex. Year 2000-2018. - SCB. URL: http://www.statistikdatabasen.scb.se/pxweb/en/ssd/START_BE_BE0101_BE0101N/ MedborgarByteTotK/?rxid=2e84560f-1b01-438e-b153-88d876705985 (accessed 21.09.2019).
} 
ности иммигрантов, высокий уровень безработицы среди них, стремление жить на пособие и нежелание интегрироваться привели к их постепенному обособлению и отодвинули планы по ускоренной адаптации и интеграции иммигрантов на неопределенное время.

Опыт миграционной политики Швеции в области интеграции иммигрантов долгое время считался наиболее удачным. Он основывался на том, что уровень жизни иммигрантов и автохтонного населения должен быть приблизительно одинаковым, потому что в ином случае это могло стать источником социальной и политической напряженности и привести к ущемлению прав иммигрантов. Не будем забывать, что Швеция благодаря политике «открытых дверей» является второй после Германии страной по привлекательности для иммигрантов (см. рис. 1).

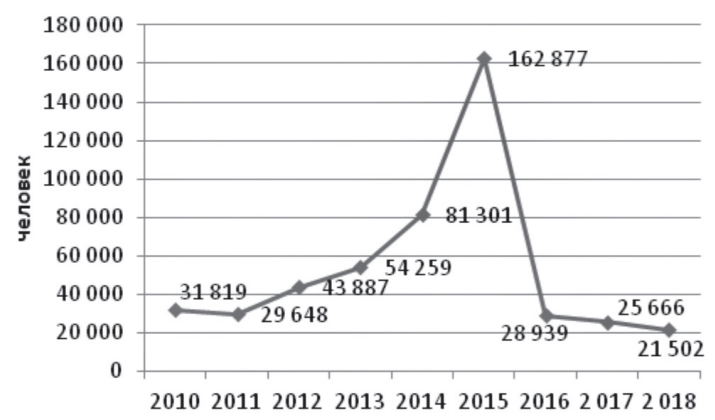

Рисунок 1. Число лиц, ищущих убежища в Швеции, 2010-2018 гг. ${ }^{1}$

По данным миграционного управления страны, Швеция является третьей по величине страной-реципиентом в мире для квотных ${ }^{2}$ беженцев, поскольку квота за 2 года увеличилась с 1900 чел. до 5000 (в 2017 г. квота увеличилась до 3400 мест, а в 2018 г. она увеличилась еще на 1600 мест) ${ }^{3}$. Здесь именно правительство определяет, какой должна быть квота на беженцев, и из каких стран оно готово их принимать. Только с начала 2018 г. шведское миграционное управление совершило 9 деловых поездок в Нигер, Египет и Турцию для того, чтобы оценить ситуацию с беженцами на месте, и еще 3 поездки были запланированы до конца года. Когда квотные беженцы прибывают в Швецию, они поступают в распоряжение муниципалитета, который организует работу по обеспечению их жильем и всем необходимым для жизни.

Вместе с тем правительство Швеции с конца 2015 г., когда ощутимо возрос приток беженцев, приняло ряд мер по ужесточению миграционной политики. К примеру, с 4 января 2015 г. Стокгольм установил режим пограничного контроля на Эресуннском мосту 4 , чтобы остановить поток нелегальных иммигрантов в страну. Иммигранты, прибывающие в страну, могут надеяться лишь на временный вид на жительство. «Для получающих же статус беженца срок будет

\footnotetext{
1 https://www.migrationsverket.se/Om-Migrationsverket/Statistik.html (проверено 22.10.2019).

222 сентября 2015 г. в Брюсселе было принято решение об установлении квот при распределении беженцев по странам ЕС.

3 https://www.migrationsverket.se/Om-Migrationsverket/Pressrum/Nyhetsarkiv/Nyhetsarkiv-2018/201810-04-Snart-ar-malet-om-5-000-kvotflyktingar-till-Sverige-natt.html (проверено 22.10.2019).

4 Эресуннский мост длиной 7,8 км был построен между датским Копенгагеном и шведским Мальме в 2000 г.
} 
ограничен тремя годами, а для лиц, нуждающихся в защите на других основаниях, - 13 месяцами. Временный вид на жительство может стать постоянным, если беженец сумеет найти работу и обеспечить достаточный уровень дохода» ${ }^{1}$.

Строгие ограничения коснутся и закона о воссоединении семей: беженцы, сумевшие получить вид на жительство, должны будут сами содержать себя и членов своей семьиㄹ․ Вводится и требование к жилью достаточного размера и стандарта, где все они могли бы жить вместе. В то же время группы общества, представляющие различные гуманитарные и общественные организации, говорят о гуманитарном подходе в политике предоставления убежища и требуют справедливости в процессе предоставления убежища. Они борются против расизма и атмосферы ксенофобии и, что более значимо, пытаются обеспечить конкретную социальную, юридическую и моральную поддержку просителям убежища в таких вопросах, как жилье, юридическая поддержка и борьба с принудительным возвращением или депортацией. Новаторская инициатива университета Гетеборга дать возможность стажировки вновь прибывшим ученым из числа беженцев с целью их скорейшей интеграции была поддержана шведским правительством. Оно поручило всем шведским правительственным учреждениям, включая университеты, предложить стажировку беженцам, которым недавно было предоставлено убежище [Alaraj et al. 2019].

Эмиграционная история Финляндии в исторической ретроспективе была представлена крупномасштабной эмиграцией начала XX в. в Канаду и США, эмиграцией во время Второй мировой войны (в основном детей и женщин) в Швецию и Данию и обширной трудовой миграцией в период 1960-1970 гг. в Швецию.

Иммиграция была связана в основном с политической нестабильностью в мире в связи с различного рода военными конфликтами: это беженцы от политических режимов в своих странах (например, 182 политических беженца из Чили, бежавшие в Финляндию после военного переворота и после ухода А. Пиночета вернувшиеся на родину). Следующим этапом являлся въезд в страну в начале 1990-х гг. граждан Сомали, которые искали спасения от гражданской войны; далее приток беженцев из Югославии, которые также бежали от войны. Миграционная ситуация осложнилась после вхождения Финляндии в состав Евросоюза. В этот период в страну потянулись мигранты из стран Восточной Европы, беженцы из мусульманских стран. В 2014 г. в Финляндию въехали 3650 чел., ищущих убежища, главным образом из Ирака, Сомали, Афганистана, также иммигранты из России. Только в течение первых 5 месяцев 2015 г. в страну въехал 1361 беженец, в основном из Сомали (446) и Ирака (454). Большая часть просителей убежища прибыла в страну из Швеции через шведский город-побратим Хапаранда - Торнио ${ }^{3}$, меньшая часть $(4,6 \%)$ - с территории России 4 . И лишь самая малая часть просителей убежища прибыла в Финляндию прямым перелетом или морским путем (на пароме из Эстонии, Швеции или Германии). Конечно, многие надеются на помощь государства, на пособия. Но помощь предоставляется не всем. Если у заявителя есть собствен-

\footnotetext{
${ }^{1}$ Швеция ужесточила миграционные законы. - Взгляд. Деловая газета. 20.07.2016. Доступ: https:// vz.ru/news/2016/7/20/822544.html (проверено 21.10.2019).

2 https://www.migrationsverket.se/Om-Migrationsverket/Migration-till-Sverige/Olika-skal-foruppehallstillstand.html (проверено 21.10.2019).

3 Торнио (фин. Tornio, швед. Torneå) - городская коммуна в Финляндии, в провинции Лаппи. Хапаранда (швед. Haparanda, фин. Haaparanta) - населенный пункт на севере Швеции.

4 Migri (2016-2017). Statistics on Asylum and Refugees. URL: http://migri.fi/en/statistics (accessed 21.09.2019); Finnish Border Guard (2015-2016). News from the Border Guard. URL: http://www.raja.fi/ tietoa/tiedotteet (проверено 22.10.2019).
} 
ные сбережения или же он трудоустраивается и начинает получать зарплату, ему либо выдают меньшую сумму или не платят пособие совсем ${ }^{1}$.

В настоящее время в связи с сокращением миграционного потока число людей, записанных как просители убежища в Финляндии, ежемесячно уменьшается на полтысячи человек (см. рис. 2). Часть просителей получают вид на жительство в стране и уезжают из центров по приему беженцев, а часть вовсе покидают Финляндию или попросту уходят из центров по личным мотивам [Гаджимурадова 2018: 140].

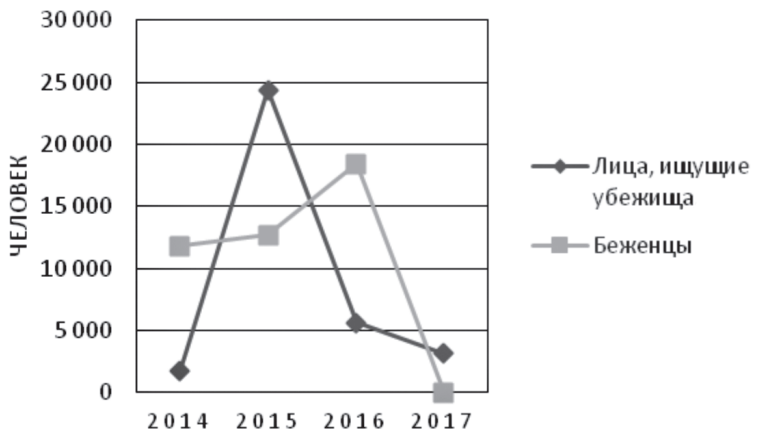

Рисунок 2. Число беженцев и лиц, ищущих убежища в Финляндии, 20142017 гг. ${ }^{2}$

Таким образом, миграционный кризис 2014-2016 гг. сыграл определенную роль в изменении миграционной политики Швеции и Финляндии в сторону ее ужесточения. Финляндия и Швециия, преследуя похожие цели, все же по-разному подходят к их реализации. Для Швеции первоочередной является задача решения проблем самосегрегации мусульманских иммигрантов и их дальнейшей интеграции в шведское общество. Финская же модель миграционной политики нацелена на реализацию политики постепенной адаптации и интеграции иммигрантов с возможностью их дисперсного расселения.

\section{Список литературы}

Alaraj H., Allelin M., Amundsen Bergström M., Brudin Borg C. 2019. Internship as a Mean for Integration. A Critical Study. - Journal of International Migration and Integration. Vol 20. Is. 2, May. P. 1-18.

Гаджимурадова Г.И. 2018. Опыт миграционной политики некоторых стран Северной Европы и возможность его применения в России (по результатам качественного исследования в лагере беженцев в Финляндии), - Власть. Т. 26. № 4. C. 139-142.

\footnotetext{
1 https://tass.ru/mezhdunarodnaya-panorama/2648389 (проверено 22.10.2019).

2 https://www.unher.org/search?comid=56b079c44\&\&cid=49aea93aba\&tags=globaltrends (проверено 12.09.2019).
} 
GADZHIMURADOVA Gyulnara Il'yasbekovna, Cand.Sci. (Philos.), Associate Professor of the Chair of Demographic and Migration Policy, Moscow State Institute of International Relations, University of the Ministry of Foreign Affairs of the Russian Federation (76 Vernadskogo Ave, Moscow, Russia, 119454); Leading Researcher of the Institute for Social and Political Studies, Russian Academy of Sciences (bld. 1, 6 Fotievoj St, Moscow, Russia, 119333; gadzhimuradova7@ gmail.com)

\title{
THE MAIN ASPECTS OF THE MIGRATION POLICY OF SWEDEN AND FINLAND
}

\begin{abstract}
The article provides a comparative analysis of some aspects of the migration policy of Sweden and Finland. The author gives the retrospective of the migration history of the two countries and the current state of affairs regarding the asylum seekers and refugees in Sweden and Finland.

Keywords: migration, immigrants, migration policy, Northern Europe
\end{abstract}

\section{УДК 94(517)}

БАЗАРОВ Виктор Борисович - кандидат исторических наук, научный сотрудник Института монголоведения, буддологии и тибетологии СО РАН (670047, Россия, Республика Бурятия, г. Улан-Удэ, ул. Сахьяновой, 6; bazarov_science@mail.ru)

\section{СТРАТЕГИЧЕСКОЕ ПАРТНЕРСТВО ВО ВНЕШНЕЙ ПОЛИТИКЕ МОНГОЛИИ}

\begin{abstract}
Аннотация. Статья посвящена пяти стратегическим партнерствам Монголии во внешней политике. В первой части работы автор раскрывает понятие «стратегическое партнерство» в отечественной историографии, показывает разные оценки этого понятия и точки соприкосновения исследователей. Во второй части работы автор анализирует каждое из пяти стратегических партнерств Монголии в хронологическом порядке: Россия, Япония, Китай, Индия и США, дает сравнительную характеристику базовых документов и динамики развития отношений.

Ключевые слова: внешняя политика Монголии, Российская Федерация, Япония, КНР, Республика Индия, США, стратегическое партнерство
\end{abstract}

$\Pi$ онятие «стратегическое партнерство», по мнению российских и зарубежных исследователей, появилось в международной практике и активно использовалось после «холодной войны». Отсутствие четкого определения стратегического партнерства вынудило исследователей данного феномена самим попытаться дать определение или хотя бы передать суть явления, выявить определенные его черты. Некоторые ученые подошли к вопросу с лингвистической стороны. Так, И.А. Новиков в работе «Стратегическое партнерство как феномен международной политики (анализ отношений Россия - Евросоюз)», разбирая этимологию слов «стратегия» и «партнерство», предложил следующую формулировку стратегического партнерства: долговременное сотрудничество на международном уровне по большому числу вопросов с целью получения максимальных выгод для себя и партнера [Новиков 2010: 118]. При этом автор постарался выделить критерии стратегического партнерства: обоюдная заинтересованность партнеров в сотрудничестве и большое число сфер для сотрудничества; принципиально важные стратегические цели, достижение которых 